\title{
PENERAPAN KONSEP FUTURISTIK PADA PUSAT PACUAN KUDA DI JENEPONTO
}

\author{
Wasilah*1 $^{* 1}$, Burhanuddin, ${ }^{2}$, Nahda Ulmia ${ }^{3}$ \\ Universitas Islam Negeri Alauddin Makassar \\ e-mail: ${ }^{* 1}$ wasilah@uin-alauddin.ac.id, 20amin.burhanuddin@gmail.com, ${ }^{3}$ nahda51@gmail.com
}

\begin{abstract}
Abstrak_ Pusat Pacuan Kuda di Jeneponto merupakan kompleks kegiatan olahraga berkuda dimana didalamnya terdapat tiga kegiatan berkuda yaitu olahraga, pelatihan dan rekreasi. Metode yang digunakan adalah metode deskriptif kualitatif. Metode ini memaparkan fakta fenomena dan keadaan kondisi eksisting tapak, kemudian disesuikan dengan data dengan studi pustaka dan studi preseden yang berkaitan dengan arena berkuda serta Arsitektur Futuristik. Konsep ini mengahsilkan perancangan bentuk bangunan yang dibuat berdasarkan pengolahan tapak yang diolah dengan bentuk dinamis dan material yang maju di dukung oleh sistem teknologi masa depan.
\end{abstract}

Kata kunci : Pusat Pacuan Kuda; Jeneponto; Arsitektur Fututristik.

\begin{abstract}
The Equestrian Center at Jeneponto is a complex of horse-riding activities where there are three riding activities that are sports, training and recreation.. The method used is qualitative descriptive method. This method describes the facts of the phenomenon and the condition of the existing site conditions, then adjusted to the data by literature study and study of precedents related to equestrian arena and Futuristic Architecture. This concept produces the design of building forms based on the processing of the treads processed with dynamic forms and advanced materials supported by future technology systems.
\end{abstract}

Keywords : The Equestrian Center; Jeneponto; Futuristic Architecture.

\footnotetext{
${ }^{1}$ Universitas Islam Negeri Alauddin Makassar

${ }^{2}$ Universitas Islam Negeri Alauddin Makassar

${ }^{3}$ Universitas Islam Negeri Alauddin Makassar
} 


\section{PENDAHULUAN}

Kabupaten Jeneponto merupakan salah satu kabupaten dari Provinsi Sulawesi Selatan yang terkenal dengan hasil pertanian, budaya dan tradisi yang kental. Ciri khas Kabupaten Jenneponto ialah kuda yang digunakan sebagai tranportasi dokar, membajak sawah, dan tradisi lomba pacuan kuda. Untuk itu Kabupaten Jeneponto dikenal dengan nama "Bumi Turatea" karena familiar dengan julukan kota "Kuda" sejak jaman dulu dan hingga saat ini. Hal ini dapat dilihat pada logo Kabupaten Jenneponto yaitu terdapat gambar kuda. Selain itu, terdapat patung kuda sebagai Icon atau simbol Kabupaten Jenneponto.

Berdasarkan data Badan Pusat Statistik Provinsi Sulawesi Selatan tenteng populasi ternak menurut Kabupaten/Kota di Sulawesi Selatan (2015) menyatakan Kabupaten Jeneponto merupakan daerah dengan populasi ternak kuda tertinggi yaitu 43,33\% dari keseluruhan jumlah total populasi ternak kuda di Provinsi Sulawesi Selatan.Untuk mewadahi kegiatan olahraga berkuda dibutuhkan bangunan dengan fasilitas yang fleksibilitas, inovatif dan mengikuti perkembangan terkini. Bangunan untuk olahraga berkuda merupakan bangunan dengan skala besar dan mempunyai tuntutan dan persyaratan tersendiri yang mengikuti perkembangan olahraga berkuda sendiri.

Arsitektur Futuristik merupakan konsep bangunan yang mengarah masa depan, fleksibel, bentuk bebas yang dekonstruksi dengan menggunakan bahan-bahan terkini yang estetis, inovatif dan ramah lingkungan. Menurut Haryadi, dkk (2015), Arsitektur Futuristik terdiri dari 3 yaitu: 1) Fasad yang dinamis di wujudkan melalui adaptasi bangunan terhadap lingkungannya terlihat dalam tampilan bangunan, 2) Estetis dan inovatif dalam mengikuti perkembangan teknologi, 3) Ramah terhadap lingkungan dengan adanya perubagan dinamis yang tidak mengganggu bangunan dan lingkungan yang sudah mapan.Untuk itu aspek ini yang menjadi pertimbangan dalam desain bangunan dengan skala besar seperti bangunan arena berkuda.

Dengan dasar kebutuhan fasilitas olahraga berkuda dan pelestarian budaya lokal Kabupaten Jeneponto akan adanya sarana dan prasarana untuk arena pacuan kuda di Kabupaten Jeneponto dengan konsep Futuristik, maka Peneliti melakukan penelitian dengan mengidentifikasi dari aspek arsitektur, kondisi dan fungsinya. Tujuan perancanagan arena pacuan kuda ialah memberikan efek yang baik dalam bidang perekonomian di Jeneponto. Hal ini dapat memacu para peternak kuda dalam meningkatkan kualitas ternaknya dan meningkatkan ekonomi para pedagang kuda di Jeneponto.

\section{METODE}

Secara umum, metode yang digunakan adalah Metode Deskriptif Kualitatif. Metode ini memaparkan fakta fenomena dan keadaan kondisi eksisting tapak, kemudian disesuikan dengan data dengan studi pustaka dan studi preseden yang berkaitan dengan arena berkuda serta Arsitektur futuristik. Selanjutnya menyimpulkan data dalam bentuk konsep desain pada Pacuan Kuda Cente.

Tahap perancangan mengurai unsur-unsur Arsitektur Futuristik menurut Haryadi, (2015) sebagai berikut:

1. Fasad yang dinamis di wujudkan melalui adaptasi bangunan terhadap lingkungannya terlihat dalam tampilan bangunan.

2. Estetis dan inovatif dalam mengikuti perkembangan teknologi.

3. Ramah terhadap lingkungan dengan adanya perubagan dinamis yang tidak mengganggu bangunan dan lingkungan yang sudah mapan. 


\section{HASIL DAN PEMBAHASAN}

\section{A. Lokasi Perancangan}

Lokasi perancangan Pusat Pacuan Kuda di Jeneponto terletak di Kecamatan Binamu, Kelurahan Empoang Selatan, Kota Bontosunggu. Lokasi ini diresmikan oleh Gubernur Sulawesi Selatan pada bulan Oktober 2011 yang juga berupakan lokasi kegiatan pestival A'jarang setiap tahun pada acara HUT Kabupaten Jeneponto. Kondisi lokasi yang disesuaikan dengan bangunan Ramah terhadap lingkungan.

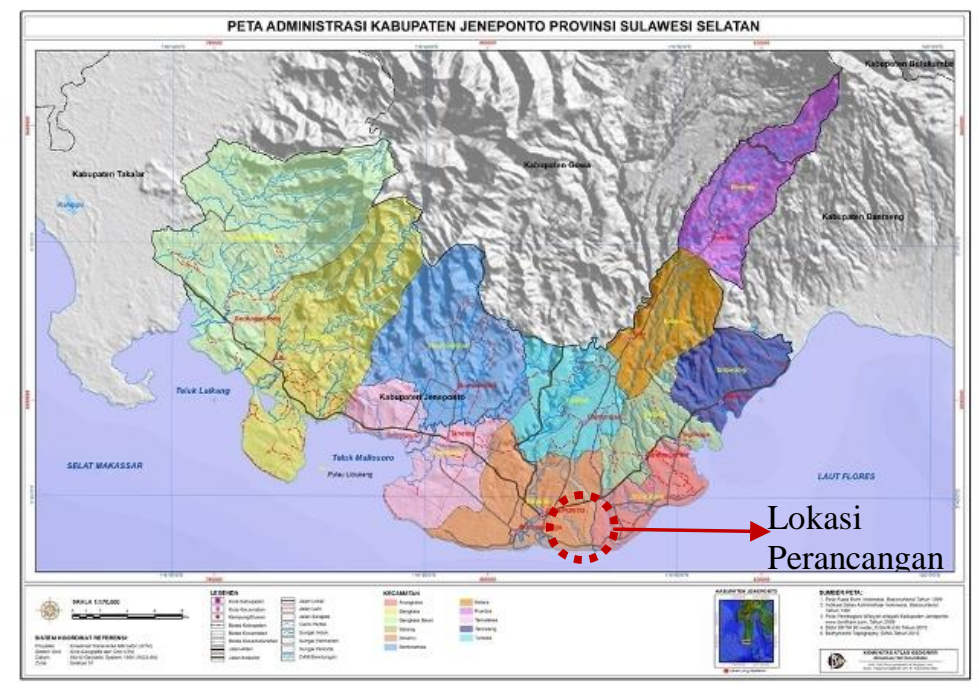

Gambar 1: Lokasi perancangan

(Sumber : Olah Data, 2017)

\section{B. Tata Guna Lahan}

Tata guna lahan berpegaruh terhadap sirkulasi, lingkungan dan kepadatan aktivitas yang terjadi di dalam kawasan. Perletakan setiap aktivitas dan kondisi lingkungan. Area depan digunakan untuk area rekreasi yang merupakan tempat umum. Aktivitas olahraga di letakkan pada bagian depan seperti area ketangkasan berkuda, area polo berkuda kemudian area pacuan berkuda. Arean pelatihan di letakkan pada bagian belakang untuk memberikan kesan privasi kepada pengguna. area belakang merupakan area pacuan berkuda yang sudah ada.

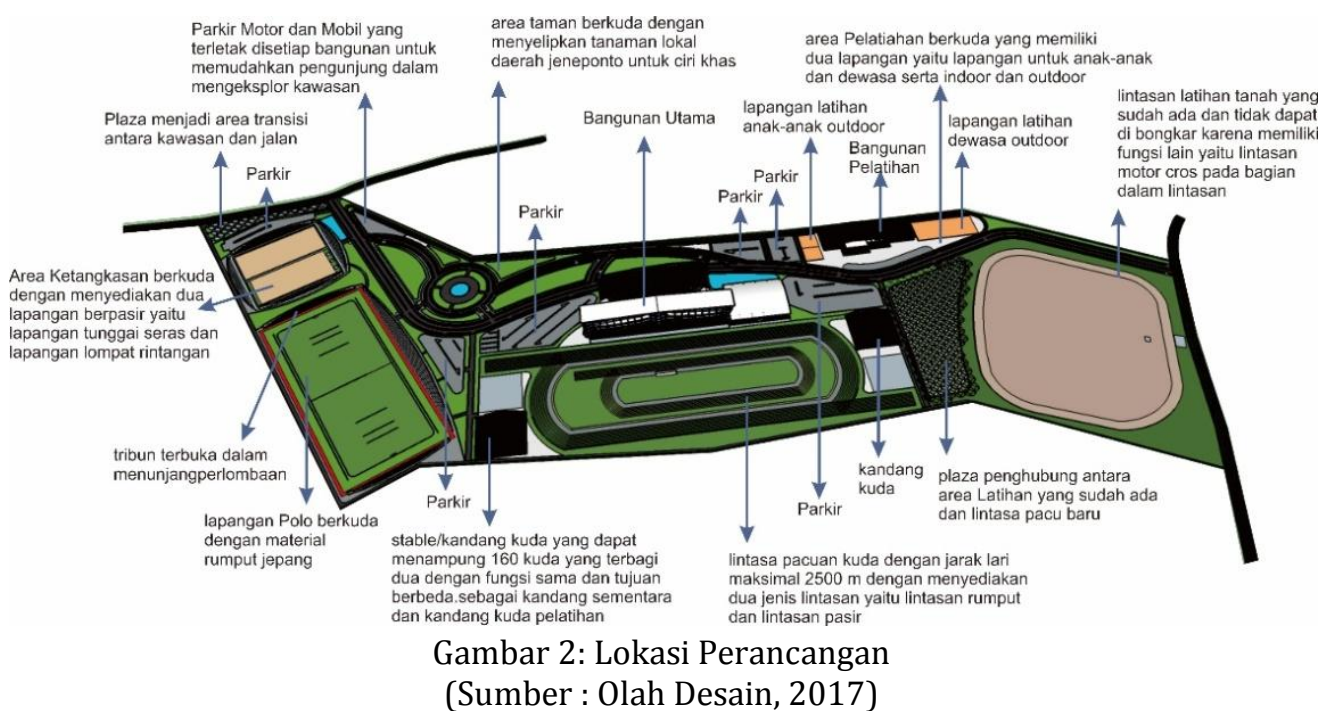

\section{Sirkulasi}


Sirkulasi dalam kawasan menghubungakn jalan lingkar pada bagian depan dan jalan pedesaan pada bagian belakang, yang merupakan akses masuk dan keluar kawasan. Untuk akses di dalam kawasan terdapat jalur untuk pejalan kaki dan jalur kuda.

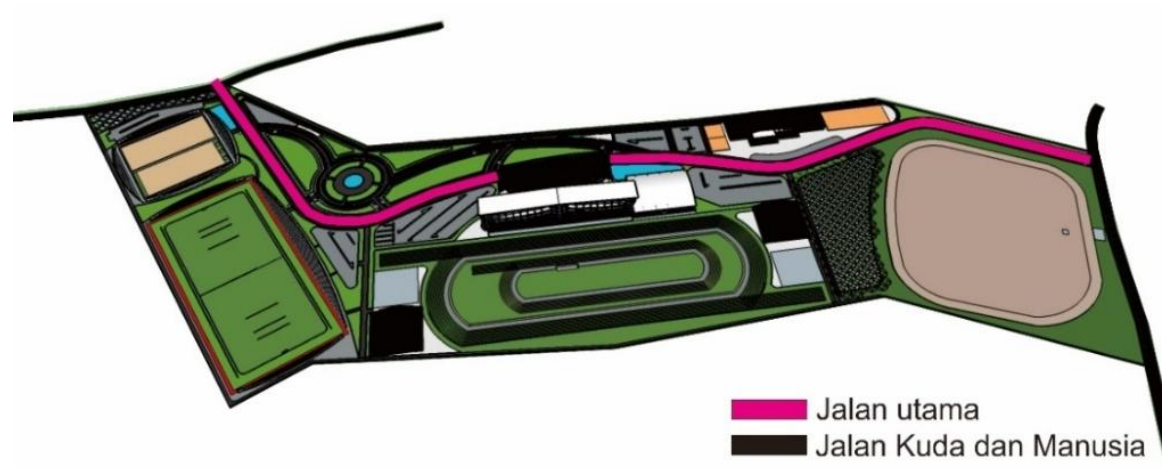

Gambar 3: Lokasi Perancangan

(Sumber : Olah Desain, 2017)

\section{Parkir}

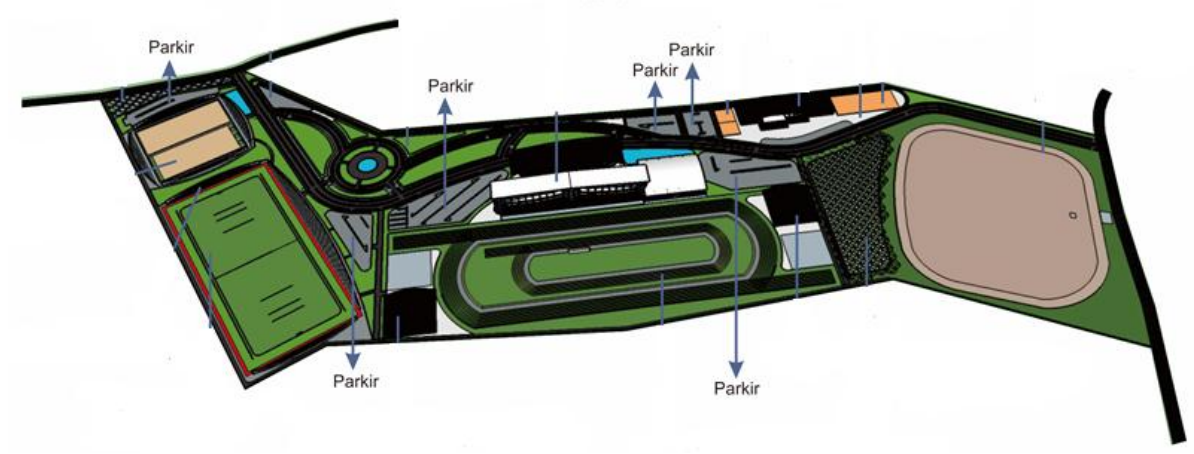

Gambar 4: Site Plan

(Sumber : Olah Desain, 2017)

Parkiran berkonsep secara menyebar di sepanjang jalur utama untuk memudahkan akses kendaraan keluar masuk kawasan.

\section{Bentuk Fasad Bangunan}

\section{Bentuk Bangunan}

Bentuk bangunan memanfaatkan pola dalam tapak sehingga menghasilkan bentuk yang stabil dalam tapak. Bentuk bangunan stadion pacuan kuda mengikuti alur fungsi lintasan dengan mempertimbangkan kebutuhan dan besaran ruang. Kandang kuda / stable tetap mengikuti standar kandang kuda pada umumnya. 
a. Bangunan Utama

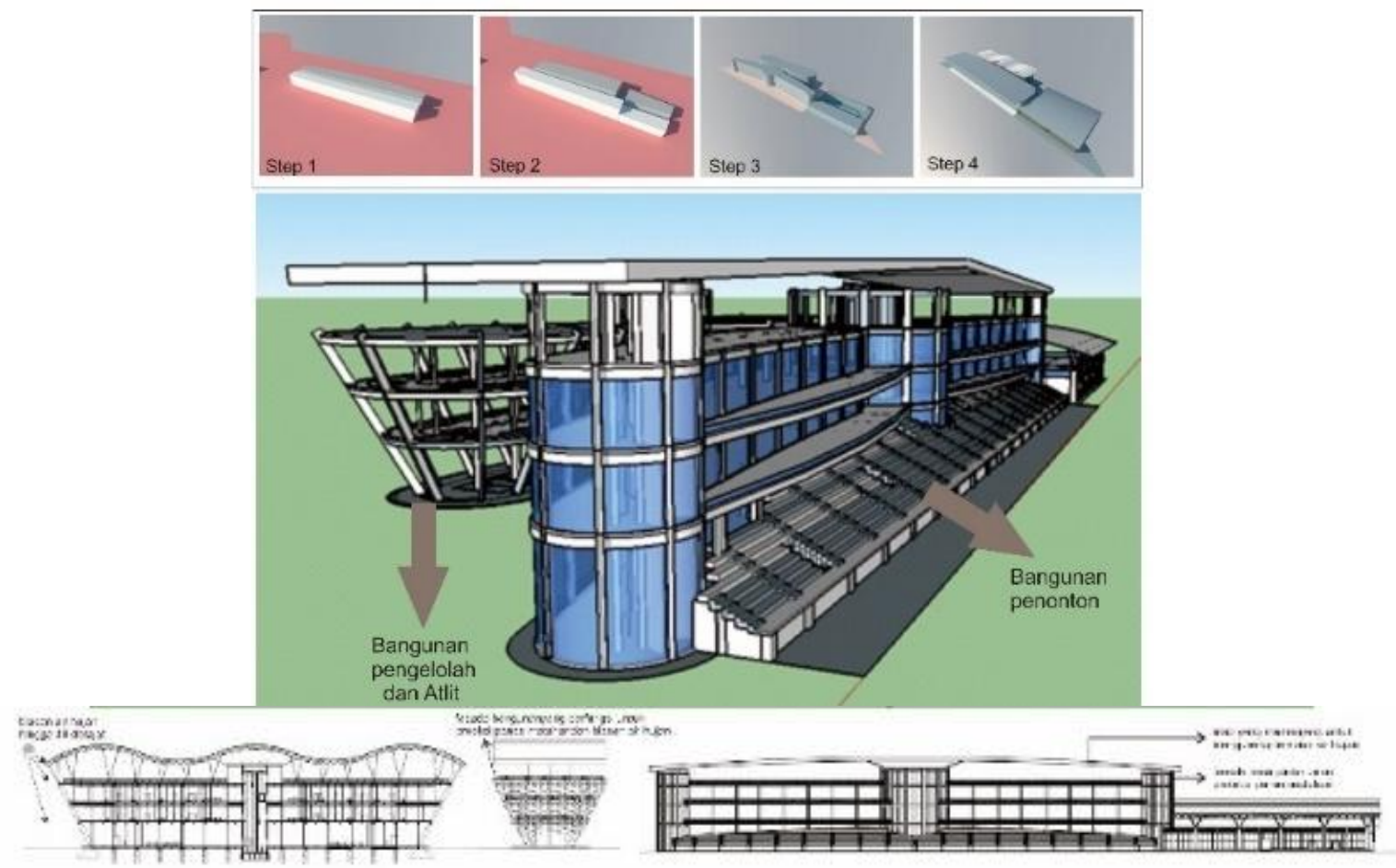

Gambar 5: Bentuk Bangunan Utama

(Sumber: Hasil Desain, 2017)

Banguan utama terbagi menjadi dua yaitu bangunan khusus untuk pengunjung atau penonton dan bangunan untuk pengelolah dan atlit.

b. Bangunan Pelatihan

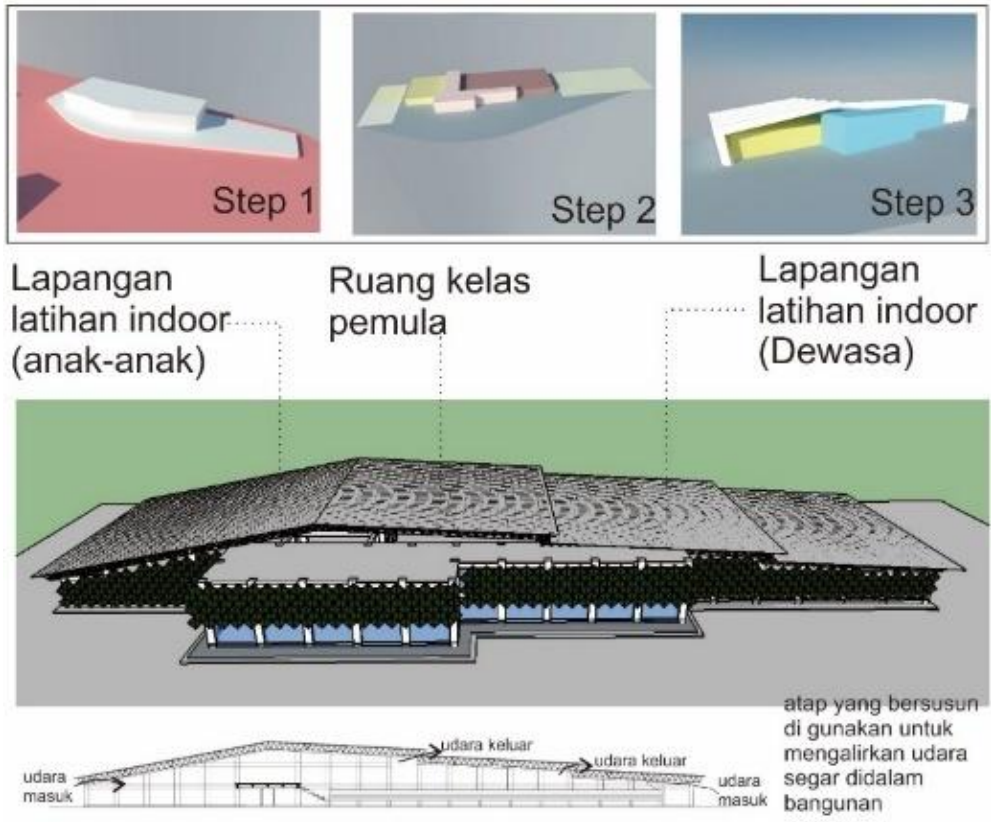

Gambar 6: Bentuk Bangunan Pelatihan

(Sumber: Olah Desain, 2017) 
Stadion ketangkasan berkuda memiliki bentuk yang elips atau melingkar karena lapangan pertandingan yang tidak terlalu besar dan memungkinkan untuk menyatukan bangunan dengan lingkaran. Stadion polo berkuda mengunakan bentuk yang sama dengan stadion pacuan kuda dengan pola yang selaras untuk menciptakan bentuk yang menyatu dalam tapak. Banguan polo berkuda dan ketangkasan berkuda merupakan bangunan yang terbuka. Area latihan indoor mengikuti standar bangunan latihan indoor pada umumnya.

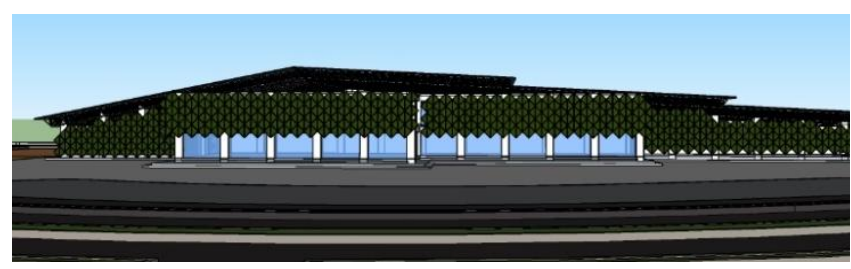

a. Tampak depan

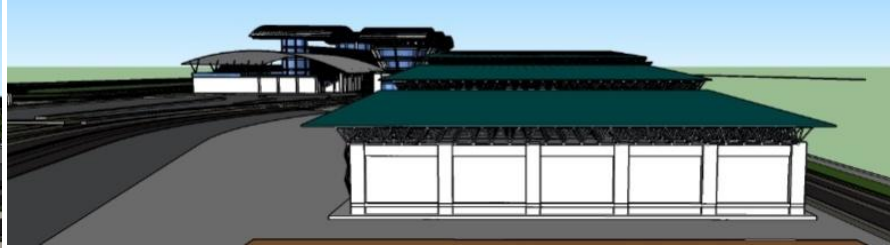

b. Tampak Samping

Gambar 7: Tampak Bangunan Pelatihan

(Sumber: Desain Akhir, 2017)

c. Bangunan Stable atau Kandang Kuda

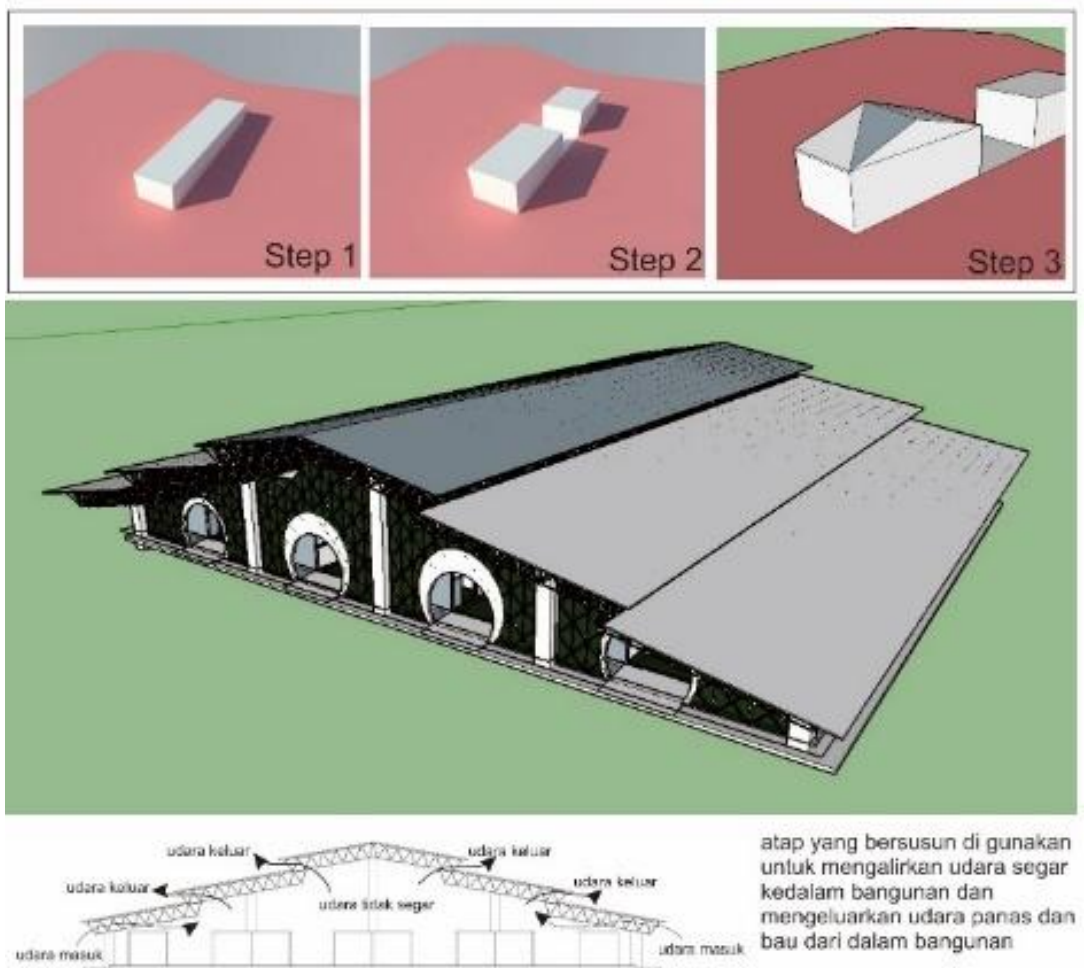

Gambar 8: Bentuk Bangunan Stable atau Kandang Kuda

(Sumber: Olah Desain, 2017) 


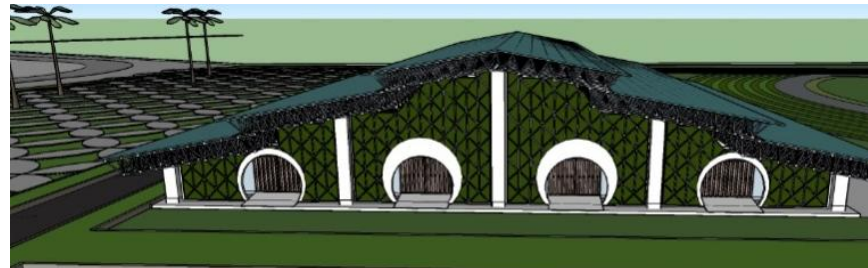

a. Tampak depan

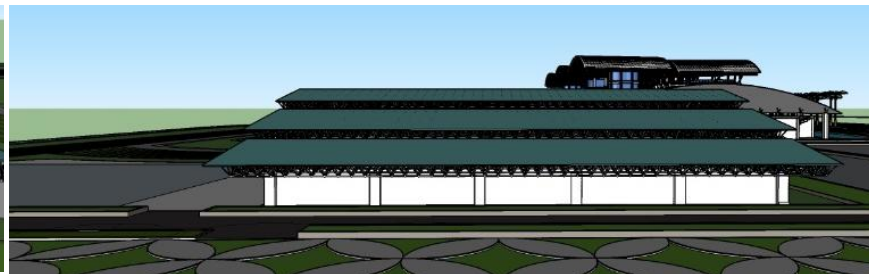

b. Tampak Samping

Gambar 9: Tampak Bangunan Kandang Kuda / Stable

(Sumber: Olah Desain, 2017)

\section{Fasad Bangunan}

Fasad yang dinamis di wujudkan melalui tampilan bangunan. Fasad bangunan diletakkan pada sisi depan bangunan sebagai citra tampilan yang ditonjolkan dari tampak bangunan. Selain sebagai pengatur cahaya yang masuk kedalam bangunan juga sebagai tampilan yang menarik yang selalu berubah-ubah sesuai dengan intensitas cahaya.

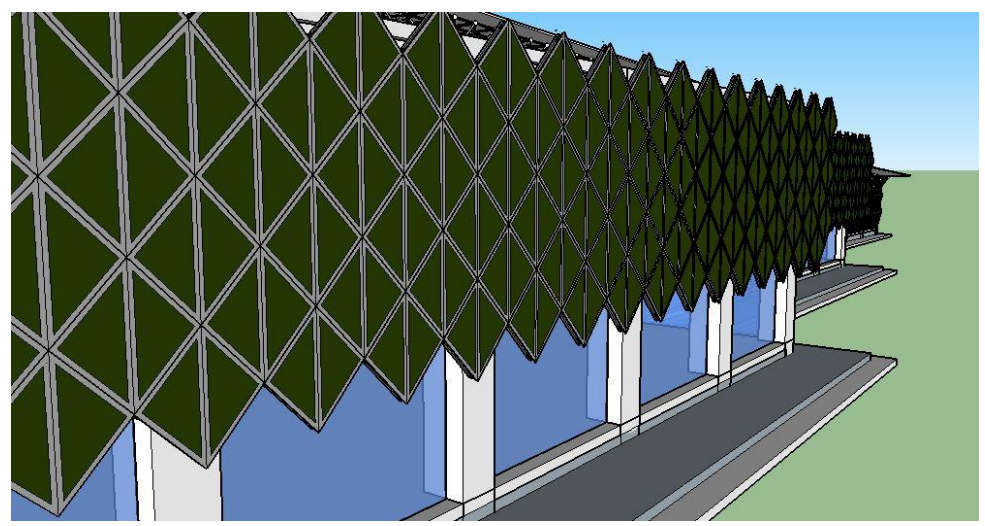

Gambar 10: Fasad Bangunan

(Sumber: Hasil Desain, 2017)

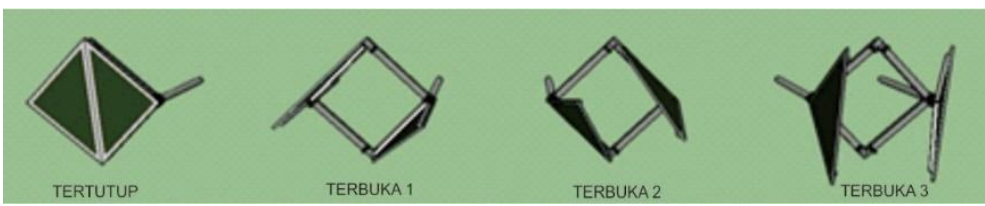

Gambar 11: Bukaan Fasad Bangunan

(Sumber: Olah Desain, 2017)

\section{Inovasi teknologi}

Sensor ditetapkan pada fasad bangunan yang dapat memantau kondisi cahaya dan hawa yang dibutuhkan kedalam bangunan. Sistem pengendalian ini digunakan untuk memantau besarnya cahaya dan suhu dalam bangunan melalui modul fasad. 


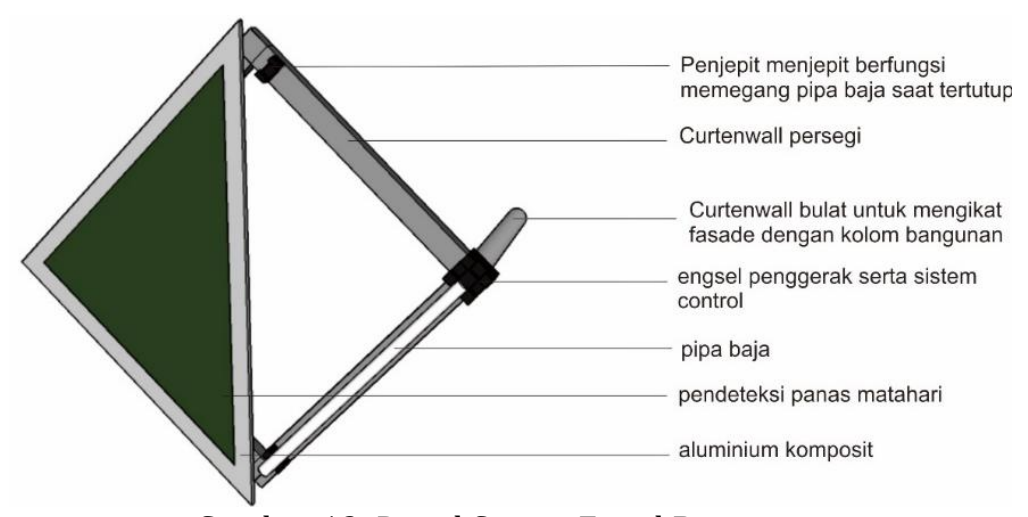

Gambar 12: Detail Sistem Fasad Bangunan

(Sumber: Olah Desain, 2017)

Fasad kaca pintar yang manpu merespon perubahan kondisi lingkungan alami menurut waktu selama sehari dengan cara sedemikian rupa untuk mereduksi kebutuhan energi untuk pemanasan, pendinginan, dan pencahayaan uang meberikan kontribusi pada konservasi lingkungan.

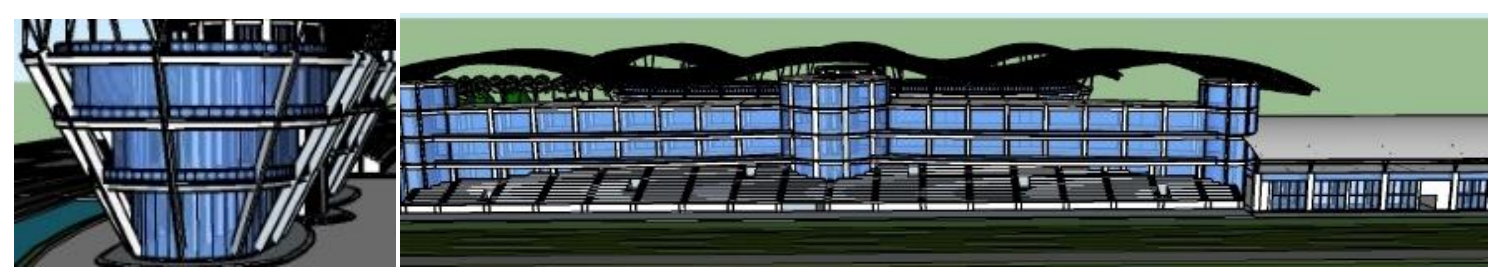

Gambar 13: Penggunaan Kaca Pintar pada Fasade bangunan

(Sumber: Olah Desain, 2017)

\section{Kebutuhan Ruang dan Besaran Ruangan} estetis.

Kebutuhan ruang dan besaran ruangan yang menciptakan membentuk bangunan yang

Tabel: Luas Kawasan

\begin{tabular}{|c|c|c|c|c|}
\hline No & $\begin{array}{c}\text { Pembagian Area Dalam } \\
\text { Kawasan }\end{array}$ & $\begin{array}{l}\text { Luas } \\
\text { Awal }\end{array}$ & $\begin{array}{l}\text { Luas } \\
\text { Akhir }\end{array}$ & Satuan \\
\hline $\begin{array}{l}1 \\
2 \\
3 \\
4\end{array}$ & $\begin{array}{l}\text { Luas area Lintasan Pacu } \\
\text { Luas area lapangan Polo } \\
\text { Luas Area Lapangan } \\
\text { Ketangkasan } \\
\text { Luas Area Latihan }\end{array}$ & $\begin{array}{l}6.54 \\
2,26 \\
0,81 \\
0,57\end{array}$ & $\begin{array}{l}5,7 \\
2,8 \\
1,2 \\
0,6\end{array}$ & $\begin{array}{l}\text { Hektar } \\
\text { Hektar } \\
\text { Hektar } \\
\text { Hektar } \\
+\end{array}$ \\
\hline & Jumlah & 10,15 & 10,3 & Hektar \\
\hline 5 & Sirkulasi $30 \%$ & 3,05 & 3,9 & Hektar \\
\hline 6 & Ruang terbuka hijau $50 \%$ & 5,07 & 5,15 & Hektar \\
\hline 7 & $\begin{array}{l}\text { Koefisien dasar banguan (KDB) } \\
20 \%\end{array}$ & 2,03 & 2,06 & Hektar \\
\hline & Total & 20,3 & 21,41 & Hektar \\
\hline
\end{tabular}


Hasil :

Luas tapak perencanaan : 21,4 hektar

Luas bangunan hasil desain : 56310,88 $\mathrm{m}^{2}=5,6$ hektar

Persentase terbangun : 5,6/21,4 x100 $=26,2 \%$ di bulatkan $26 \%$

Luas open space : $21,4-5,6$ hektar $=15,8$ hektar

Persentase : $15,8 / 21,7 \times 100=73,8 \%$ di bulatkan $74 \%$

\section{E. Struktur Bangunan}

Struktur Bangunan yang mengikuti fungsi ruang dengan mewujudkan fleksibilitas hubungan ruang dalam bangunan. Material yang digunakan dalam kawasan disesuaikan dengan fungsi dan kebutuhan pengguna. Material dalam bangunan diantaraya:

1. Beton untuk menampilkan kesan berat, massif, dan dingin.

2. Baja untuk kesan kokoh, kuat, industrialis.

3. Kaca untuk kesan ringan, transparan, melayang.

4. Gaya penataan moden futuristik melalui permainan warna.

5. Menggunakan latar warna hitam, putih dan perak yang kontras dengan warna alam.

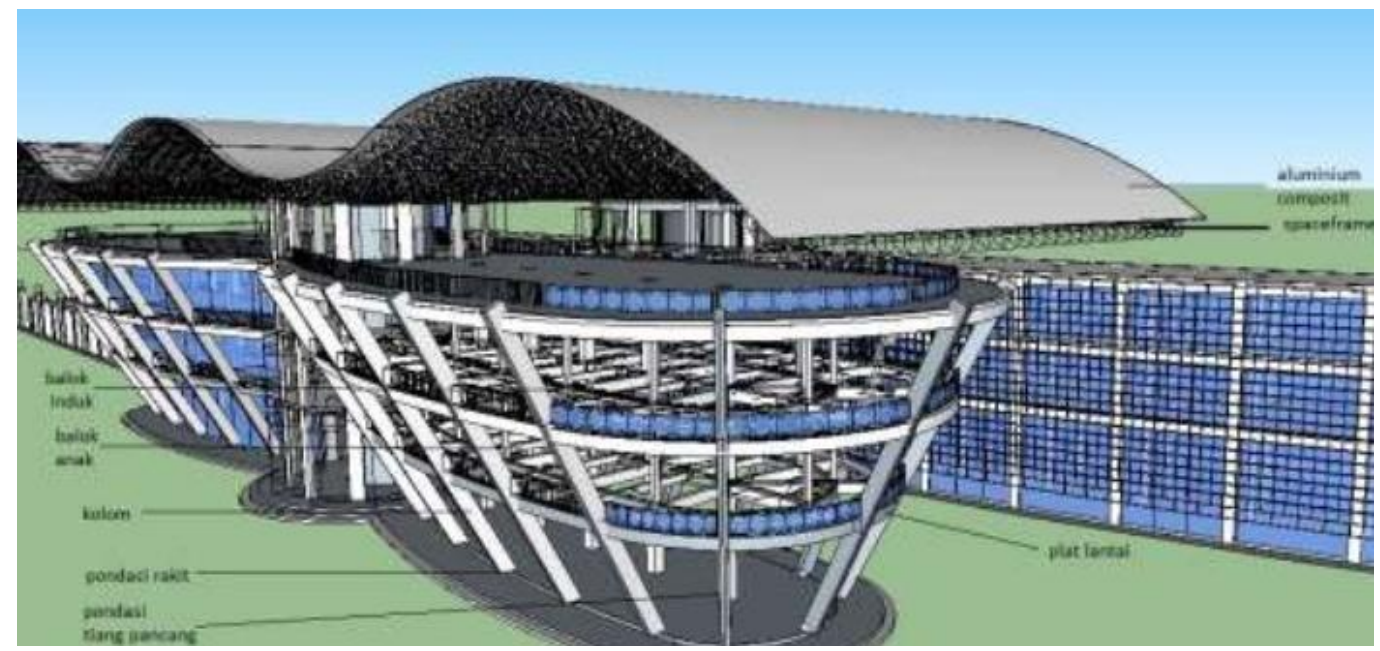

Gambar 14: Bangunan Stable atau Kandang Kuda

(Sumber: Olah Desain, 2017)

Menentukan sitem struktur dan konstruksi pada bangunan-bangunan dalam kawasan Pusat Pacuan Kuda di Jeneponto dengan memepertimbangkan beban bangunan, fungsi serta daya dukung tanah. Sistem struktur disetiap sisi bangunan berbeda berdasarkan pada sisi bangunan yang terkena matahari akan berbeda perlakuannya dengan sisi yang tidak terkena panas matahari. 


\section{KESIMPULAN}

Penerapan konsep futuristik pada lokasi pusat pacuan kuda yang disesuaikan dengan bangunan ramah terhadap lingkungan. Fasad yang dinamis di wujudkan melalui tampilan bangunan. Inovatif dalam mengikuti perkembangan teknologi. Kebutuhan ruang dan besaran ruangan yang menciptakan membentuk bangunan yang estetis. Struktur yang mengikuti fungsi ruang dengan mewujudkan fleksibilitas hubungan ruang dalam bangunan. Konsep

\section{DAFTAR REFERENSI}

Archambault, Ariane dan Jean-Claude Corbell. Visual With Definitions.

Arinta Safitri, Ristya. (2012). Pengembangan Arena Pacuan Kuda Tengalwaton Kabupaten Semarang Sebagai Pusat Kegiatan Berkuda Di Jawa Tengah. Semarang. Universitas Dipenegoro.

Cing, Francis D.K dan Corky Binggeli. (2011). Desain Interior Dengan Ilustrasi Edisi Kedua. Jakarta. PT Indeks.

C.Snyder, James. 1994. Pengantar arsitektur. Jakarta, Erlangga

De Chiara, Joseph dan John Chalender. (2001). Time Saver Standard of Building Tipe Fourth Edition. Singapore. Mc Graw Hill.

Dudek, Mark. (2000). Arsitektural of School New Learning Enviromental. London. Arsitektur Press.

Dudek, Mark. (2007). A Design Manual School and Kindergartens. German. Birkhauzer.

Duerk, Donna.P. 1993. Arsitektural Programing Information Management For Desing. New York. Van Nostrand Reinhold.

Dwi Astuty, Vinia. (2011). Rivitabilitas Sifat Kemampuan Kuda Pacu Indonesia Mempertahankan Kecepatan Berlari. Bogor. Institut Pertanian Bogor.

Haryadi, Syala, Ratna Amanati dan Pedia Aldy (2015) Pekanbaru Convention Center Dengan Penekanan Bangunan Futuristik. Jom Fteknik 2 (1) : 1-14.

Makowski. (1988). Konstruksi ruang Baja. Bandung. Penerbit ITB.

Neufert, Ernst. (1991). Data Arsitek Jilid 1 Edisi 33. Jakarta. Penerbit Erlangga.

Neufert, Ernst. (1991). Data Arsitek Jilid 2 Edisi 33. Jakarta. Penerbit Erlangga.

Sumalyo, Yulianto. (2005). Arsitektur Modern Akhir Abad XIX dan Abad XX Edisi ke-2. Yogyakarta. Gadjah Mada University Press.

Standar SNI 03-3647-1994. Departemen Pekerjaan Umum. Tata Cara Perencanaan Teknik Bangunan Gedung Olahraga. 1994. Yayasan LPMB Bandung.

Sulyanto. (2010). Pusat Olahraga Berkuda di Surakarta. Universitas Katolik Soegijapranata.

Syalam Haryadi dkk. (2015). Pekan Baru Compention Center Dengan Penekanan Bangunan Futuristic.

Tim Karya Tani Mandiri. (2010). Pedoman Budidaya Berternak Kuda. Bandung. Nuansa Aulia. 